\title{
THE EFFECT OF CADMIUM ON GROWTH OF VEGETATIVE THALLUS AND DEVELOPMENT OF GENERATIVE ORGANS OF CHARA VULGARIS L. AFTER SHORT TIME OF CULTIVATION
}

\author{
ALEKSANDRA GOSEK, MARIA KWIATKOWSKA, ROBERT DUSZYŃSKI \\ Department of Cytophysiology, University of Łódź \\ 90-237 Łódź, ul. Pilarskiego 14, Poland
}

(Received: July 9, 1996. Accepted: December 18, 1996)

\begin{abstract}
The effect of cadmium ions in two different concentrations $\left(10^{-8} \mathrm{M} \mathrm{i} 10^{-6} \mathrm{M}\right)$ on vegetative thallus, male (antheridia) and femele (oogonia) generative organs of Chara vulgaris L. was investigated. After 9 days of growth in a presence of cadmium the number of lateral branches decreased and the lengths of internodes of the main axis and pleuridia became shortened. The increase in oospores volume and decrease in antheridial volume (both total and internal) after 3, 7 and 9 days of cultivation were observed. The productivity of antheridium measured by the number of antheridial filaments and number of cells within filament is also lower in plants cultivated with cadmium in comparison with control ones.
\end{abstract}

KEY WORDS: Cadmium, Chara, generative organs.

\section{INTRODUCTION}

The environmental pollution manifested by increase in heavy metals concentrations in water and air puts in front of plants the high adaptative requirements and it can be disscussed as one of the stress factors. The plant organisms have shown much higher tolerance for this kind of pollution than animals.

Cadmium - metal used in present investigations is one of the most toxic among the set of heavy metals. The presence of cadmium cations induces in plants widely observed morphological deformations, anatomical changes and physiological disturbances (Lepp and Roberts 1977). The following effects of cadmium ions have been observed: the inhibition of root and stem growth (Wong and Bradshaw 1982; Arduini et al. 1994), changes in water translocation (Barcelo et al. 1988), deformation in leaves surface and disturbances in chlorophyll synthesis leading to chlorosis (Bazzaz and Govindjee 1974; Poschenrieder et al. 1983; Krupa et al. 1993). On the cell level one can find the reduction in mitotic activity (Biessonova 1991], changes in course of cytokinesis (Gabara and Gołaszewska 1992), reduction of nuclear and cytoplasmic dry mass (Romaniuk and Gabara 1988) and cell vacuolization (Barcelo et al. 1988) which can be a result of modifications in membranes permeability.

Cadmium cations initiate a lot of changes in the cell structure like budding or ER fragmentation, many different deformations inside plastids (Heumann 1987), and reduction of mitochondria number (Silverberg 1976). Moreover metal ions modificate nuclear shape, the course and level of DNA replication (Mehishuk et al. 1982), number and size of nucleoli and their metabolic activity (Romaniuk and Gabara 1988).
Chara vulgaris L. - as a eukaryotic freshwater alga is an especially convenient model for this kind of studies because of the earlier investigations which well defined its thallus growth and development of generative organs in physiological conditions. Also inside antheridia (male generative organs) there is a population of antheridial filaments containing within particular filament almost synchronously dividing cells (Olszewska 1974).

The studies performed on this object by Heumann (1987) were concentrated on reaction of the apical parts of thallus against the different heavy metal ions during long time of cultivation. He has found the decrease in the length of vegetative cells of thallus and observed pathological structure of chloroplasts and local disturbances in cell wall construction.

The aim of present studies was: 1) to find out the effects of cadmium cations used in two different concentrations $\left(10^{-6} \mathrm{M}\right.$ and $10^{-8} \mathrm{M}$ ) on the growth of vegetative thallus cells 2 ) to check the action of these cations on volume of male (antheridia) and female (oogonia) generative organs and 3.) to define the productivity of antheridia and spermatids size after short time (3, 7 and 9 days) of cultivation.

\section{MATERIAL AND METHODS}

The material for studies were freshwater alga - Chara vulgaris L. growing in Botanical Garden in Rogów, Poland. Apical parts of thallus containing generative organs were cultivated in water from natural habitat (control series) and in solution of cadmium $\left(\mathrm{CdCl}_{2}\right)$ in $10^{-8} \mathrm{M}$ and $10^{-6} \mathrm{M}$ concentrations also made in water from natural environment. The cultivation was performed in room temperature in natural photo- 
period $(\mathrm{L}: \mathrm{D}=14: 10)$. The number of nodes, lateral branches and the length of internodes and pleuridia were measured using the photographs of the plants at the start and at the end of experiment. The plants were fixed in Carnoy'a mixture after 3, 7 and 9 days and were preserved in $70 \%$ ethanol.

Morphometric measurements of antheridia and oospores diameters were made with the use of ocular micrometr in light microscope at magnification $5 \times 10$.

The total and internal volume of antheridium was estimated from formula:

$$
V=\frac{4}{3} \Pi r^{3}
$$

where for total volume we used measured total radius but for internal volume the measured internal radius.

Volume of oospores was estimated from formula:

$$
V=\Pi r^{2} h
$$

where $\mathrm{h}$ was the length of oospore and $\mathrm{r}$ - half of its diameter measured in the widest section.

After staining with orcein for 45 minutes in $60^{\circ} \mathrm{C}$ and in Fast Green for 2 minutes in room temperature, the squashed preparations from antheridia in spermatogenesis were made. During their analysis the number of antheridial filaments inside antheridium, the average number of cells in one filament and the length of spermatids were estimated.

All the results were analysed statistically. Standard error (SE) and significance of differences using Student's test at $\mathrm{p}=0.05$ were calculated. At figures 4,5 the value of standard error is lower than the unit on axis, so it cannot be expressed graphically.

\section{RESULTS}

\section{The number of nodes and lateral branches}

Both experimental concentrations of cadmium $\left(10^{-8} \mathrm{M}\right.$ and $10^{-6} \mathrm{M}$ ) caused the decrease in the number of lateral branches of the main axis on the similar level. There was no significant effect on the number of newly formed nodes of thallus (Table 1).

TABLE 1. The number of newly formed nodes and lateral branches of Chara vulgaris thallus after 9 days of cultivation with cadmium cations.

\begin{tabular}{l|c|c}
\hline & Number of nodes & $\begin{array}{c}\text { Number } \\
\text { of lateral branches }\end{array}$ \\
\hline Control & $2.2 \pm 0.2$ & $0.43 \pm 0.1$ \\
\hline $10^{-8} \mathrm{M} \mathrm{Cd}^{2+}$ & $1.9 \pm 0.2$ & $0.23 \pm 0.1$ \\
\hline $10^{-6} \mathrm{M} \mathrm{Cd}^{2+}$ & $1.7 \pm 0.2$ & $0.21 \pm 0.1$ \\
\hline
\end{tabular}

\section{The growth of axial internodes}

The increase in axial internodes length was measured as the difference between their lengths at the start and at the end (after 9 days) of experiment. The internodal cells on thallus were numbered from the oldest (I) to the youngest (VI).

The internodes I, II, III had already been formed before the administration of cadmium cations and IV, V, VI were formed and developed during experiment.

Both used cadmium solutions decreased the length of internodal cells proportionally to their concentrations (Fig. 1). The maximum effect was observed for the second (II) and the third (III) internodal cells.

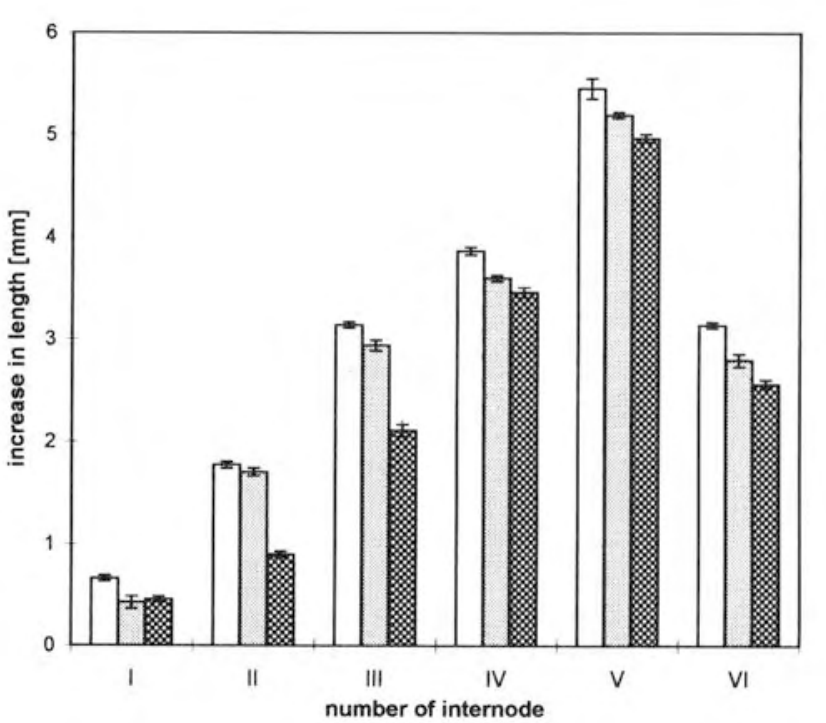

Control

$10^{-8} \mathrm{M} \mathrm{Cd}^{2+}$ $10^{-6} \mathrm{M} \mathrm{Cd}^{2+}$

Fig. 1. The increase in the axial internodes of Chara vulgaris vegetative thallus after 9 days of cultivation with cadmium cations

\section{The growth of pleuridia}

Cadmium cations in concentration $10^{-8} \mathrm{M}$ caused the decrease in pleuridia length only in the youngest nodes (VI, VII). The pleuridia from plants treated with $\mathrm{Cd} 10^{-6} \mathrm{M}$ were shorter in comparison with control ones for all investigated nodes (Fig. 2).

\section{Volume of oospores}

In all experimental periods of cultivation one can observe the statistically significant increase in volume of oospores in lower cadmium concentration $\left(10^{-8} \mathrm{M}\right)$. The higher one $\left(10^{-6}\right.$

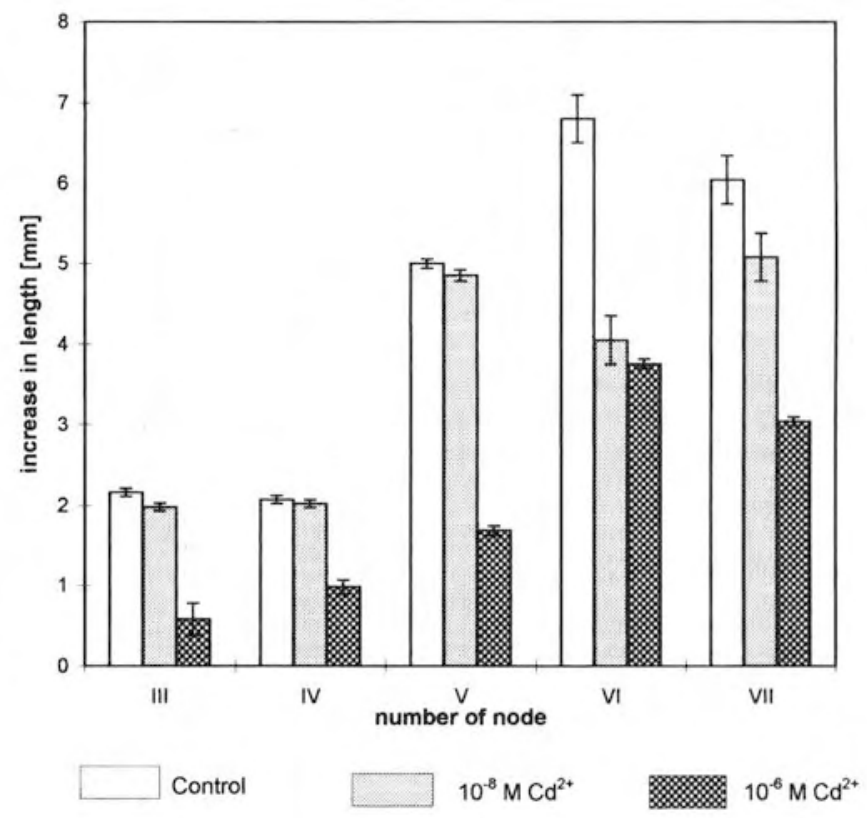

Fig. 2. The increase in length of pleuridia of Chara vulgaris vegetative thallus after 9 days of cultivation with cadmium cations 
M) has shown the strong stimulatory effect only after 7 days of cultivation (Fig. 3).

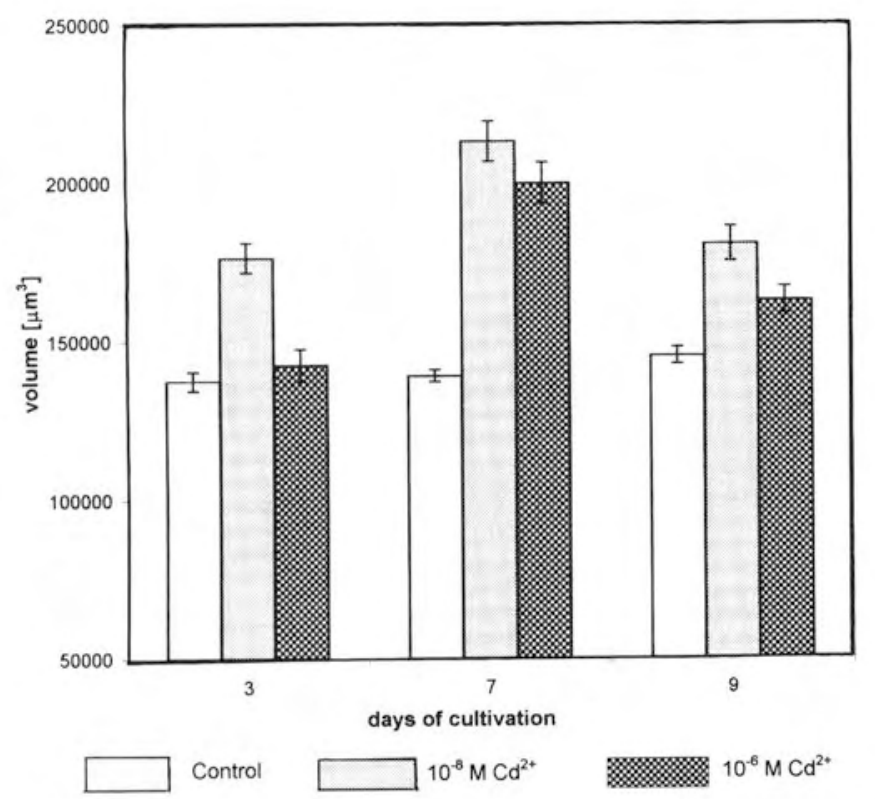

Fig. 3. Volume of oospores of Chara vulgaris after 3, 7 and 9 days of cultivation with cadmium in different concentrations

\section{Total volume of antheridium}

Already after 3 days of cultivation with cadmium (Fig. 4a) the decrease in total volume of antheridia at all developmental stages was observed. The stronger effect was evidenced for antheridia treated with lower metal concentration. After 7 (Fig. 4b) and 9 (Fig. 4c) days of cultivation, the total volume of investigated antheridia was lower than in control ones. The strongest effect was found for antheridia treated with metal in higher $\left(10^{-6} \mathrm{M}\right)$ concentration.

\section{Internal volume of antheridium}

During formation of antheridium the creation of free internal space filled with polysaccharide mucilage takes place. After 3 days of cultivation, the internal volume of antheridia treated with cadmium was a little smaller than control ones (Fig. 5a).

The prolongation of experiment to 7 and 9 days has shown much stronger inhibiting effect. It is in proportion to metal concentration with statistically significant differences (Fig. 5b, Fig. 5c). However the maximum decrease in growth of internal space of antheridium was observed in plants fixed after 7 days of experiment.

\section{The productivity of antheridium}

The biological productivity of antheridium is defined by the number of spermatozoids developing inside antheridium. This parameter depends on: 1) the mitotic activity of capitular cells determining the number of filaments and 2) the number of cellular divisions inside the filament - defining the number of cells which can transform into spermatozoids within one filament.

The cultivation in medium containing cadmium cations caused decreasing in the number of antheridial filaments inside mature antheridium (Tab. 2) in all experimental variants.
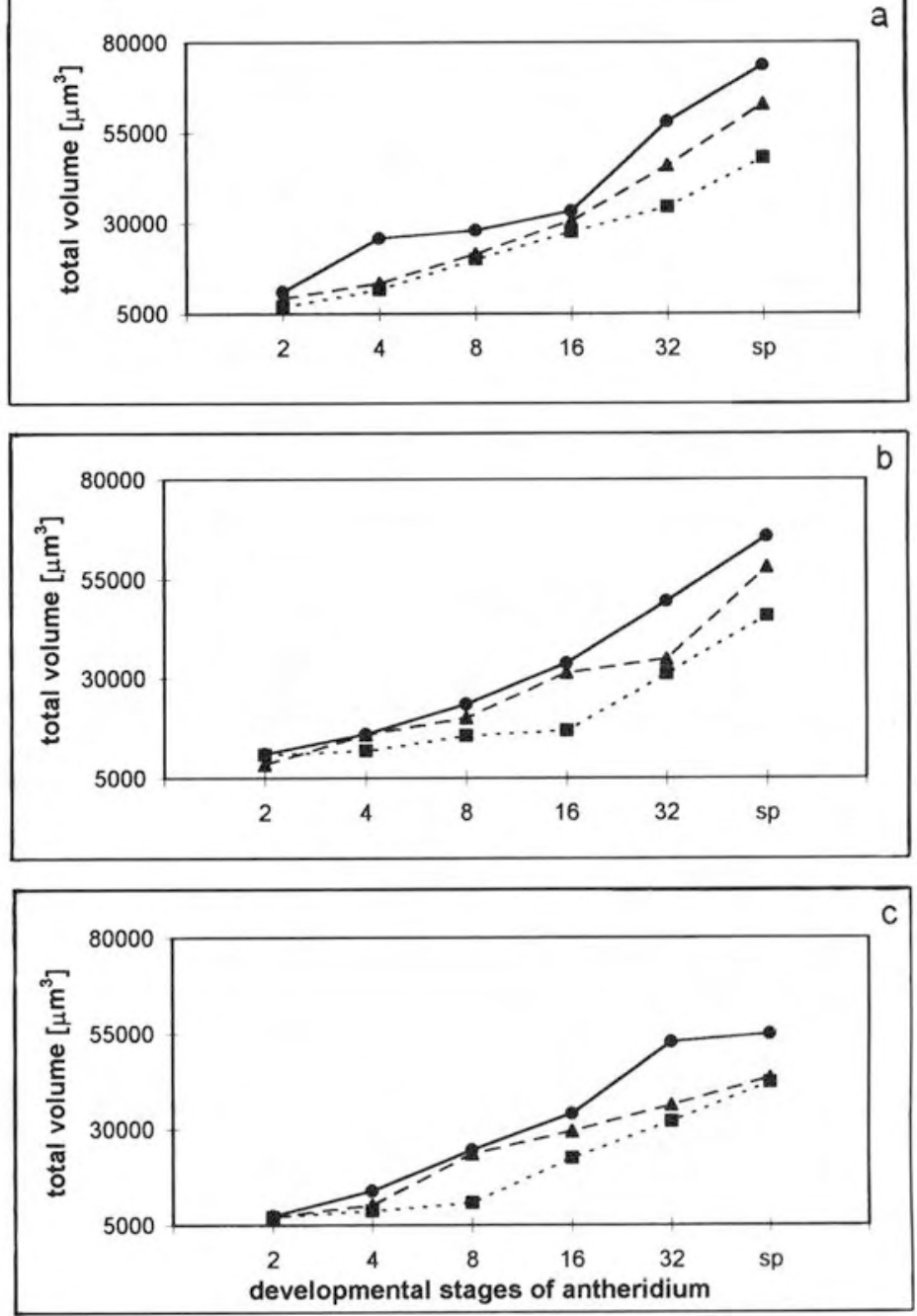

$\longrightarrow$ Control $\quad-\rightarrow-10^{-8} \mathrm{M} \mathrm{Cd}^{2+} \quad \cdots=\cdots 10^{-6} \mathrm{M} \mathrm{Cd}^{2+}$

Fig. 4. Total volume of antheridium in different developmental stages $(2,4,8,16,32$ - proliferative phase; sp - spermiogenesis) after cultivation with cadmium: a) 3 days b) 7 days c) 9 days

TABLE 2. The number of antheridial filaments inside Chara vulgaris antheridium after 3, 7 and 9 days of cultivation with cadmium cations.

\begin{tabular}{c|c|c|c}
\hline Days & Control & $10^{-8} \mathrm{M} \mathrm{Cd}^{2+}$ & $10^{-6} \mathrm{M} \mathrm{Cd}^{2+}$ \\
\hline 3 & $131.7 \pm 6$ & $93.7 \pm 10$ & $112.7 \pm 9$ \\
\hline 7 & $134.8 \pm 11$ & $103.4 \pm 9$ & $101.0 \pm 8$ \\
\hline 9 & $125.3 \pm 8$ & $94.8 \pm 8$ & $99.3 \pm 7$ \\
\hline
\end{tabular}

The average number of cells inside one antheridium also decreases after 3, 7 and 9 days of cultivation. This effect is stronger for plants treated with solutions containing higher cadmium concentration (Tab. 3). Total productivity of an-

TABLE 3. The average number of cells within antheridial filament from Chara vulgaris antheridium after cultivation with cadmium cations.

\begin{tabular}{c|c|c|c}
\hline Days & Control & $10^{-8} \mathrm{M} \mathrm{Cd}^{2+}$ & $10^{-6} \mathrm{M} \mathrm{Cd}^{2+}$ \\
\hline 3 & $91.3 \pm 3$ & $71.3 \pm 5$ & $83.5 \pm 5$ \\
\hline 7 & $100.4 \pm 3$ & $78.4 \pm 7$ & $67.1 \pm 4$ \\
\hline 9 & $86.8 \pm 4$ & $72.4 \pm 6$ & $57.7 \pm 4$ \\
\hline
\end{tabular}



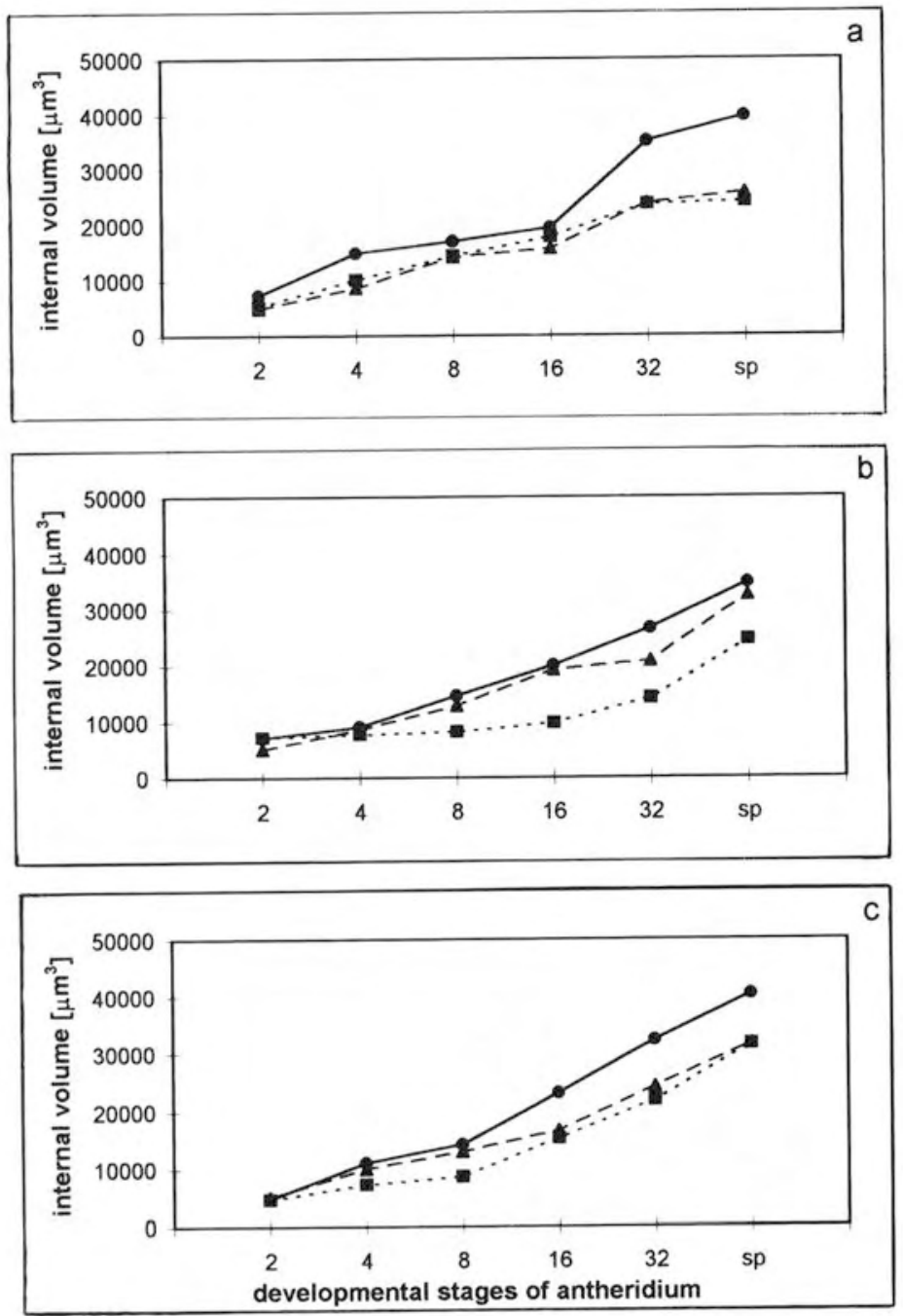

$\longrightarrow$ Control $\quad-\quad 10^{-8} \mathrm{M} \mathrm{Cd}^{2+} \quad \cdots-\cdots 0^{-6} \mathrm{M} \mathrm{Cd}^{2+}$

Fig. 5. Internal volume of antheridium in different developmantal stages $(2,4,8,16,32$ - proliferative phase, sp - spermiogenesis) after cultivation with cadmium: a) 3 days b) 7 days c) 9 days

theridium decreases in statistically significant level in all experimental variants and is stronger after 7 and 9 days (Fig. 6).

\section{The length of spermatids}

Spermatids are the cells of antheridial filaments which have finished their mitotic divisions in proliferative phase and already have initiated the process of differentiation into spermatozoids.

After 7 and 9 days of cultivation with presence of cadmium ions in both used concentrations the statistically significant increase in length of spermatids was observed (Fig. 7).

\section{DISCUSSION}

The increasing pollution of water systems disturbing the ecological balance in the last few years reduced the frequence of occurrence of Charophyta. The higher concentrations of heavy metals in environment depress growth and development of plants.

The cadmium ions induced evident morphological changes of vegetative thallus and male and female generative organs of Chara vulgaris L. The increase in volume of oogonia, can be explained by disturbances in growth of the external, shel-

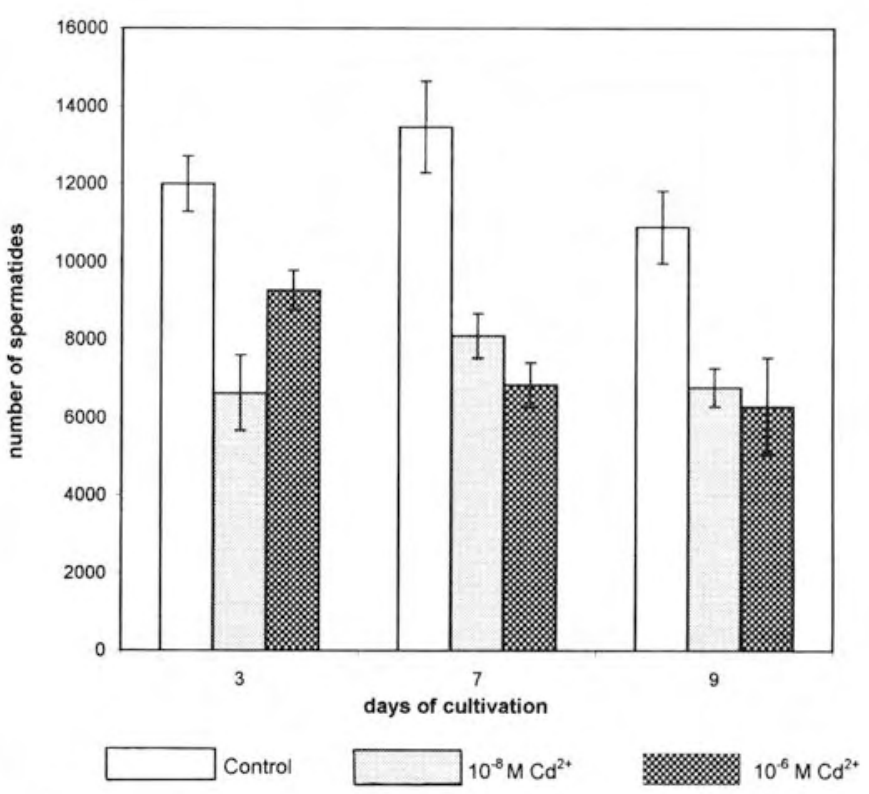

Fig. 6. The productivity of Chara vulgaris antheridium after 3, 7 and 9 days of cultivation with cadmium ions.

tering cells. It may be a result of their stronger vacuolization (Barcelo et al. 1988) or higher accumulation of starch grains and lipid granules (Visviki and Rachlin 1994).

The antheridia have shown contrary reaction - the decrease in both total and internal volume. Cadmium ions seem to block the normal and tangential growths of shield cells. According to Kwiatkowska and Żylińska (1988) both extensions determine the diameter of antheridium. As a result of this process the internal space of antheridium filled by the PASpositive, polysaccharide mucilage is lower (Gosek and Kwiatkowska 1991; Gosek 1994). The antheridia initiating sper-

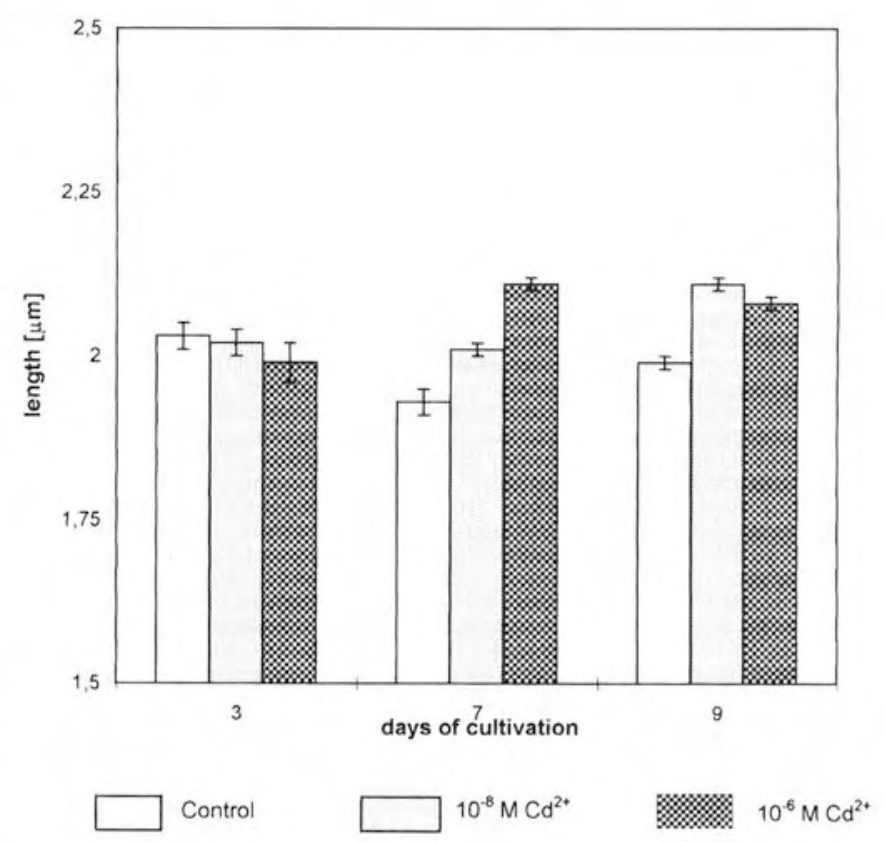

Fig. 7. The length of spermatids inside Chara vulgaris antheridium after cultivation with cadmium cations 
miogenesis (i.e. spermatozoids differentiation) treated with cadmium had the same volume as the antheridia containing filaments with 32 cells from the control plants.

In plants influenced by cadmium there was lower number of lateral branches of main axis than in control ones. It confirms the strong apical domination. The similar reduction of formation the lateral roots was observed in Phaseolus vulgaris (Vázquez et al. 1992). Decrease in the growth of internodal and pleuridial cells of vegetative thallus also may be a result of the reduction in longitudal growth observed in root and stem growth of Phaseolus vulgaris (Vázquez et al. 1992) and Pinus pinea (Arduini et al. 1994), modification in water transport (Barceló et al. 1988) or premature senescence of plants (Poschenrieder et al. 1983). The decrease in internodal length of Chara vulgaris was reported by Heumann (1987) after cultivation with solutions of different heavy metal cations like mercury and lead.

According to earlier results (Kwiatkowska and Maszewski 1987), filament mother cells develop by the budding of capitular cells. The decrease in number of filaments in antheridium allows to suggest that cadmium inhibits the mitotic activity of capitular cells. It can result from binding with DNA and blocking the replication (Mehishuk et al. 1982) or disturbances in cytokinesis caused by malformation and malfunction of microtubules (Biessonova 1991; Gabara and Gołaszewska 1992). Lower productivity of antheridium is connected both with decrease in the number of filaments and the number of cells within one filament. It is modified during the proliferative phase by the reduction of the number of the mitotic divisions. The reduction of all divisions can be attributed to lower nuclear DNA synthesis (Gabara et al. 1992) and smaller content of nuclear proteins (Wojtyła-Kuchta et al. 1991]. The similar inhibition in spores development was observed in Funaria hygrometrica (Lepp and Roberts 1977).

In presence of cadmium ions the higher length of spermatids i.e. cells initiating the spermatozoids differentiation in comparison with control was observed. One can try to explain it by disturbances in the course of physiological process of morphogenetic size reduction of cells from one generation to another (Olszewska and Godlewski 1972) or by elimination of one cell cycle.

The results of the present studies demonstrate that the common alga - Chara vulgaris is very sensitive to low dose and short time exposure to cadmium. It confirms this plant as a convenient model for investigation and suggests that further, much more complicated studies are necessary to perform for better understanding the effects and mechanisms of heavy metal action on eukaryotic plants.

\section{ACKNOWLEDGEMENTS}

This work was supported by University of Łódź - grant number $505 / 723$.

\section{LITERATURE CITED}

ARDUINI I., GODBOLD DL., ONNIS A., 1994. Cadmium and copper change root growth nd morphology of Pinus pinea and Pinus pinaster seedlings. Physiologia Plantarum 921: 675-680.

BARCELÓ J., VÁZQUEZ M.D., POSCHENRIEDER CH., 1988. Cadmium induced structural and ultrastructural changes in the vascular system of bush bean stems. Botanica Acta 101: 254-261.

BIESSONOVA W.P., 1991. Kletocznyj analiz rosta korniej Lathyrus odoratus $L$. pridiejstvi tiażełych metałov. Citoł. i Gene. 25: 18-22.
BAZZAZ M.B, GOVINDJEE, 1974. Effects of cadmium nitrate on spectral characteristics and light reactions of chloroplasts. Environ.Lett. 6: 1-12.

GABARA B., GOŁASZEWSKA E., 1992. Calcium effect on mitotic activity and frequency of mitotic disturbances in the cortex cells of Pisum sativum roots treated with heavy metals. Bull. Pol. Acad. Sci. Ser. Biol. 40: 97-103.

GABARA B., WOJTYŁA- KUCHTA B., TARCZYŃSKA M., 1992. The effect of calcium on DNA synthesis in pea (Pisum sativum) roots after treatment with heavy metals. Folia Histochem. Cytobiol. 30: 69-74.

GOSEK A., 1994. The growth of internal volume in young antheridia of some Chara species in relations to changes in antheridial mucilage concentrations during 3-day continuous darkness. Bull. Pol. Acad. Sci. Ser. Biol. 42: 263-268.

GOSEK A., KWIATKOWSKA M., 1991. Cytochemical studies on the antheridial mucilage and changes in its concentrations and amount during spermatogenesis in Chara vulgaris L. Folia Histochem. Cytobiol. 29: 91-100.

HEUMANN H.G., 1987. Effects of heavy metals on growth and ultrastructure of Chara vulgaris. Protoplasma 136: 37-48.

KRUPA Z., ÖQUIST G., HUNERN P.A., 1993. The effects of cadmium on photosynthesis of Phaseolus vulgaris - a fluorescence analysis. Physiologia Plantarum. 18: 626-630.

KWIATKOWSKA M., MASZEWSKI J., 1987. Ultrastructural and autoradiographic studies of non-generative cells of Chara vulgaris antheridium. II. Capitular cells. Folia Histochem. Cytobiol. 25: 225231.

KWIATKOWSKA M., ŻYLIŃSKA K., 1988. Ultrastructural and autoradiographic studies of non-generative cells in the antheridium of Chara vulgaris L. III. Shield cells. Folia Histochem. Cytobiol. 26: 225-236.

LEPP N.W., ROBERTS M.J., 1977. Some effects of cadmium on growth of bryophytes. Bryologist. 80: 533-536.

MEHISHUK Y., LISHKO A.K., KALININ F.J., 1982. Effect of cadmium on early stages of seed germination, RNA, protein and DNA synthesis in the pea. Fizjol.Rast. 29: 655-660.

OLSZEWSKA M.J., 1974. Antheridial filaments of Chara vulgaris - a model for study of mitotic cycle and cell differentiation. Portug. Acta. Biol. Ser. A XIV: 313-322.

OLSZEWSKA M.J., GODLEWSKI M., 1972. An autoradiographic study of the synthesis a nucleic acids and proteins during the cell cycle synchronously dividing antheridial filaments in Chara vulgaris L. Folia Histochem. Cytochem. 10: 245-256.

POSCHENRIEDER CH., CABOT C., BARCELÓ J., 1983. Influence of high concentration of cadmium on the growth, development and photosyntethic pigment of Phaseolus vulgaris. Ann. Edafol. Agrobiol. 52: 315-327.

ROMANIUK J., GABARA B., 1988. Heavy metal action on the dry mass and surface area of nuclei and cytoplasm during differentiation of cortex in pea (Pisum sativum) roots. Folia Histochem.Cytobiol. 26: 263-274.

SILVERBERG B.A., 1976. Cadmium induced ultrastructural changes in mitochondria of freshwater green algae. Phycologia. 15:155-159.

VÁZQUEZ M.D., POSCHENRIEDER CH., BARCELÓ J., 1992: Ultrastructural effects and localization of low cadmium concentrations in bean roots. New Phytologist. 120: 216-226.

VISVIKI I., RACHLIN W., 1994. Acute and chronic exposure of Dunaliella salina and Chlamydomonas bullosa to copper and cadmium: effects on ultarstructure. Arch. Environ. Contam. Toxicol. 26: 154162.

WONG M.H., BRADSHAW A.D, 1982. A comparison of the toxicity of heavy metals using root elongation of rye grass, Lolium perenne. New Phytol. 91: 255-261.

WOJTYŁA- KUCHTA B., GABARA B., 1991: Changes in the content of DNA and NYS-stained nuclear, nucleolar and cytoplasmic proteins in cortex cells of pea (Pisum sativum) roots treated with cadmium. Biochem. Physiol. Pflanzen. 187: 67-76. 


\section{WPŁYW KRÓTKOTRWAŁEJ HODOWLI W OBECNOŚCI JONÓW KADMU \\ NA WZROST WEGETATYWNEJ PLECHY \\ I ROZWÓJ ORGANÓW GENERATYWNYCH CHARA VULGARIS L.}

\section{STRESZCZENIE}

Badano wpływ jonów kadmu, podanych w dwu różnych stężeniach $\left(10^{-8} \mathrm{M}\right.$ i $\left.10^{-6} \mathrm{M}\right)$ na wzrost plechy i rozwój organów generatywnych (anterydiostanów i oogoniów) Chara vulgaris $L$. Po 9 dniach hodowli zaobserwowano zmniejszenie liczby tworzonych odgałęzień bocznych plechy, skrócenie długości międzywęźli i pleurydiów. Po 3, 7 i 9 dniach działania kadmu wykazano zwiększenie objętości oospor i obniżenie zarówno całkowitej, jak i wewnętrznej objętości anterydiostanów. Produktywność męskich organów generatywnych mierzona liczbą spermatyd wewnątrz anterydium jest rownież niższa u roślin hodowanych w obecności kadmu w porownaniu z kontrolą.

SŁOWA KLUCZOWE: kadm, Chara, organy generatywne. 